\title{
Minimal invasive fixation of distal tibial fractures does not result in rotational malalignment: A report of 24 cases with CT imaging
}

\author{
Mehmet Mesut Sönmez, M.D., ${ }^{1}$ Deniz Gülabi, M.D., ${ }^{2}$ Meriç Uğurlar, M.D., ${ }^{1}$ \\ Metin Uzun, M.D., ${ }^{4}$ Sezgin Sarban, M.D., ${ }^{5}$ Ali Şeker, M.D. ${ }^{3}$
}

\begin{abstract}
1'Department of Orthopedics and Traumatology, Şişli Etfal Training and Research Hospital, İstanbul-Turkey
${ }^{2}$ Department of Orthopedics and Traumatology, Kartal Dr. Lütfi Kırdar Training and Research Hospital, İstanbul-Turkey

${ }^{3}$ Department of Orthopedics and Traumatology, Medipol University Faculty of Medicine, İstanbul-Turkey

${ }^{4}$ Department of Orthopedics and Traumatology, Acıbadem University Faculty of Medicine, İstanbul, Turkey

${ }^{5}$ Department of Orthopedics and Traumatology, International Hospital, İstanbul-Turkey
\end{abstract}

\begin{abstract}
BACKGROUND: Tibial torsion is rotation of the proximal versus the distal articular axis in the transverse plane. This study used computed tomography $(\mathrm{CT})$ to examine rotational malalignment in the crus following use of minimally invasive plate osteosynthesis (MIPO) technique in distal tibial fractures and evaluated effect of rotational difference on clinical outcomes and VAS scores.
\end{abstract}

METHODS: Analysis of 24 patients who were operated on for closed distal tibial fracture with MIPO technique between 2010 and 2012 was conducted. Malrotation was defined as rotational difference $>10^{\circ}$. Operated knees were evaluated with $0.5-\mathrm{mm}$, fine-cut, 3-dimensional CT scan performed in cooperation with radiology department. Side-to-side difference in tibial torsion angle $>10^{\circ}$ was considered significant degree of malrotation. All patients were assessed clinically (visual analogue scale [VAS] and American Orthopaedic Foot and Ankle Society [AOFAS] scores) and radiologically at final visit.

RESULTS: Mean follow-up period was $20.00 \pm 9.46$ months (range: I8-5I months). Mean VAS score was $2.58 \pm 0.83$ (range: I-4) and mean AOFAS score was $87.50 \pm 4.05$ (range: 78-93). Mean tibial rotation angle was $31.54 \pm 6.00^{\circ}$ (range: $18-45^{\circ}$ ) on healthy side and $32.00 \pm 6.24^{\circ}$ (range: $10-43^{\circ}$ ) on the operated side. No statistically significant difference was determined $(p>0.05)$.

CONCLUSION: Use of intraoperative fluoroscopy, cable technique, and uninjured extremity as reference, can reduce incidence of rotational malalignment of distal tibial fractures treated with MIPO.

Keywords: CT; distal tibia fractures; malrotation; MIPO.

\section{INTRODUCTION}

Since the popularization of biological fixation, minimally invasive percutaneous plating is now used more frequently. Favorable outcomes, including shorter healing time and lower reoperation rates have been reported in the literature. ${ }^{[1,2]}$

Address for correspondence: Deniz Gülabi, M.D.

Maltepe Başıüüük Mah., Emek Cad., Tepe İnşaat Narcity Konutları,

G4: 30, İstanbul, Turkey

Tel: +90 216 - 44I 3900 / 1450 E-mail: dgulabi@yahoo.com

Qucik Response Code

Ulus Travma Acil Cerrahi Derg

2017;23(2): 144-149

doi: $10.5505 /$ tjtes.2016.59153

Copyright 2017

TJTES
Achievement of optimal position using indirect reduction methods is technically difficult and may result in lower extremity malalignment. This displacement can lead to adverse effects in adjacent joints and articular cartilage, causing earlier development of arthrosis. ${ }^{[3,4]}$

Tibial torsion is rotation of the proximal versus the distal articular axis in the transverse plane. Suero et al. ${ }^{[5]}$ found that malrotation of the distal tibia led to abnormal load distribution in the ankle joint. Considerable concern exists that malalignment of healed distal tibial fracture may result in post-traumatic arthritis of the ankle. As the location of the deformity approaches the ankle, malalignment results in maldistribution of articular surface pressures, which may then predispose a patient to premature osteoarthritis. ${ }^{[6,7]}$ It is well known that as osteoarthritis progresses, there will be reduction in ability of the patient to participate in physical and social activities. 
Using computed tomography (CT), this study examined rotational malalignment in the crus following use of minimally invasive plate osteosynthesis (MIPO) technique in distal tibial fractures, and evaluated effect of rotational difference on clinical outcomes and visual analogue scale (VAS) scores.

\section{MATERIALS AND METHODS}

Analysis of 30 patients who were operated on for closed distal tibial fracture with the MIPO technique between 2010 and 2012 was conducted. Chart notes were studied for demographic details, mechanism of injury, and type of fracture. All preoperative $X$-rays were reviewed and classified using the AO/OTA Classification of Fractures and Dislocations. Inclusion criteria were unilateral distal tibial closed fractures. Exclusion criteria were fixation or revision of previous fixation in the ipsilateral or the contralateral femur or tibia, disagreement in CT imaging, multiple fractures, 2-stage surgery, and pregnant females. Two patients who had multiple fractures, 3 patients with 2-stage surgery, and I patient with disagreement in CT imaging were excluded; thus, 24 patients were included in this study for evaluation. The patients were I I (45.8\%) males and 13 (54.2\%) females with mean age of $33.67 \pm 10.72$ years (range: 19 to 55 years). Mechanism of injury was fall from height in II (45.8\%) patients, and motor vehicle accident in $13(54.2 \%)$ patients. Fractures were classified according to the AO/OTA classification system.

All procedures followed were in accordance with the Helsinki Declaration of 1975, as revised in 2008. Approval for the study was granted by the ethics committee on human experimentation (institutional and national). Informed consent agreement was obtained from all patients for inclusion in the study.

\section{Surgical Technique}

All operations were performed within 2 days of the injury. All patients were operated on by a single surgeon. All cases were managed under regional anesthesia. Uninjured lower extremity in all patients was prepared for comparison. Image intensifier with $\mathrm{C}$-arm was used in all cases to provide fluoroscopic guidance. Longitudinal traction was applied along the foot by a junior orthopedic surgeon. Rotational alignment was achieved by aligning the anterior superior iliac spine, patella, and second ray of the foot using the cable technique. In 8 patients with concomitant tibial and fibular fractures, fibular fixation was performed initially. For fractures with intraarticular components, after fixation of articular fragments with minimal dissection, "J"-shaped medial incision $3 \mathrm{~cm}$ in length was made. Distal medial tibial plate (DePuy Synthes Companies, Zuchwil, Switzerland) was used for fracture fixation. Plate was advanced from incision submuscularly and only swab incisions were made for screw placements. Quality of reduction was verified with fluoroscopy and rotational alignment was checked clinically (Fig. Ia, b). Patients were mo- bilized on 2 crutches. Weight-bearing was permitted when callus formation was observed on radiographs at follow-up examinations. All patients were evaluated clinically and radiologically at final visit. VAS and American Orthopaedic Foot and Ankle Society (AOFAS) scores were recorded.

\section{Assessment of Radiographs}

All measurements were calculated by independent radiographic reviewer who was blinded to the study. Observer assessed all radiographs twice at an interval of I week, and mean of the 2 values was accepted as rotation degree of each tibia. Reviewer had ample time to evaluate the radiographs, as no time limit was imposed on review. Measurements were taken using PACS System (Novard Corp., American Fork, UT, USA). Internal rotation deformity was assigned negative value and external rotation was given positive value. Rotational difference $>10^{\circ}$ was defined as malrotation. Operated knees were evaluated with $0.5-\mathrm{mm}$, fine-cut, 3-dimensional CT scans (Aquilion 64; Toshiba Medical Systems Corp., Otawara, Japan) in cooperation with radiology department. Patients were scanned in supine position with adjustable supports to prevent movement of lower extremities. Scanning included multiple 5-mm cuts at the proximal tibia and distal tibia. Axial plane images were used. Proximally, reference line was the tangent to the posterior tibial ridges at level just superior to the fibular head. Tibial torsion angle was calculated using difference between angles of the proximal and transmalleolar axis just proximal to the tibial plafond with horizontal reference line (Fig. Ic). Side-to side difference in tibial torsion angle $>10^{\circ}$ was considered significant degree of malrotation. Normal value for adults quoted in the literature is $30^{\circ}$ to $40^{\circ}$ of external rotation, with range of $\pm 10^{\circ} .{ }^{[8,9]}$

\section{Statistical Methodology}

Statistical analyses were performed using NCSS 2007 (NCSS, LLC, Kaysville, UT, USA) software. Descriptive statistical methods were used (mean, SD, frequency, percentage, minimum, maximum) were used to evaluate study data. Paired samples t-test was used to compare group of variables that demonstrated normal distribution. Pearson correlation analysis and Spearman correlation analysis were used to analyze relationships between variables. Statistical significance was determined at $p<0.05$.

\section{RESULTS}

Intraobserver reliability was calculated as 0.92 . Mean followup period was 20.00 \pm 9.46 months (range: 18-5I months). Mean body mass index of the patients was $22.04 \pm \mathrm{I} .55 \mathrm{~kg} /$ $\mathrm{m}^{2}$ (range: $20-25 \mathrm{~kg} / \mathrm{m}^{2}$ ). Mean time to union was $15.42 \pm \mathrm{I} .67$ weeks (range: 13-19 weeks). Mean VAS score was $2.58 \pm 0.83$ (range: I-4) and mean AOFAS score was 87.50 \pm 4.05 (range: 78-93). (Table I).

AO fracture type was $42 \mathrm{Al}$ in 3 cases (I2.5\%), $42 \mathrm{~A} 3$ in I 

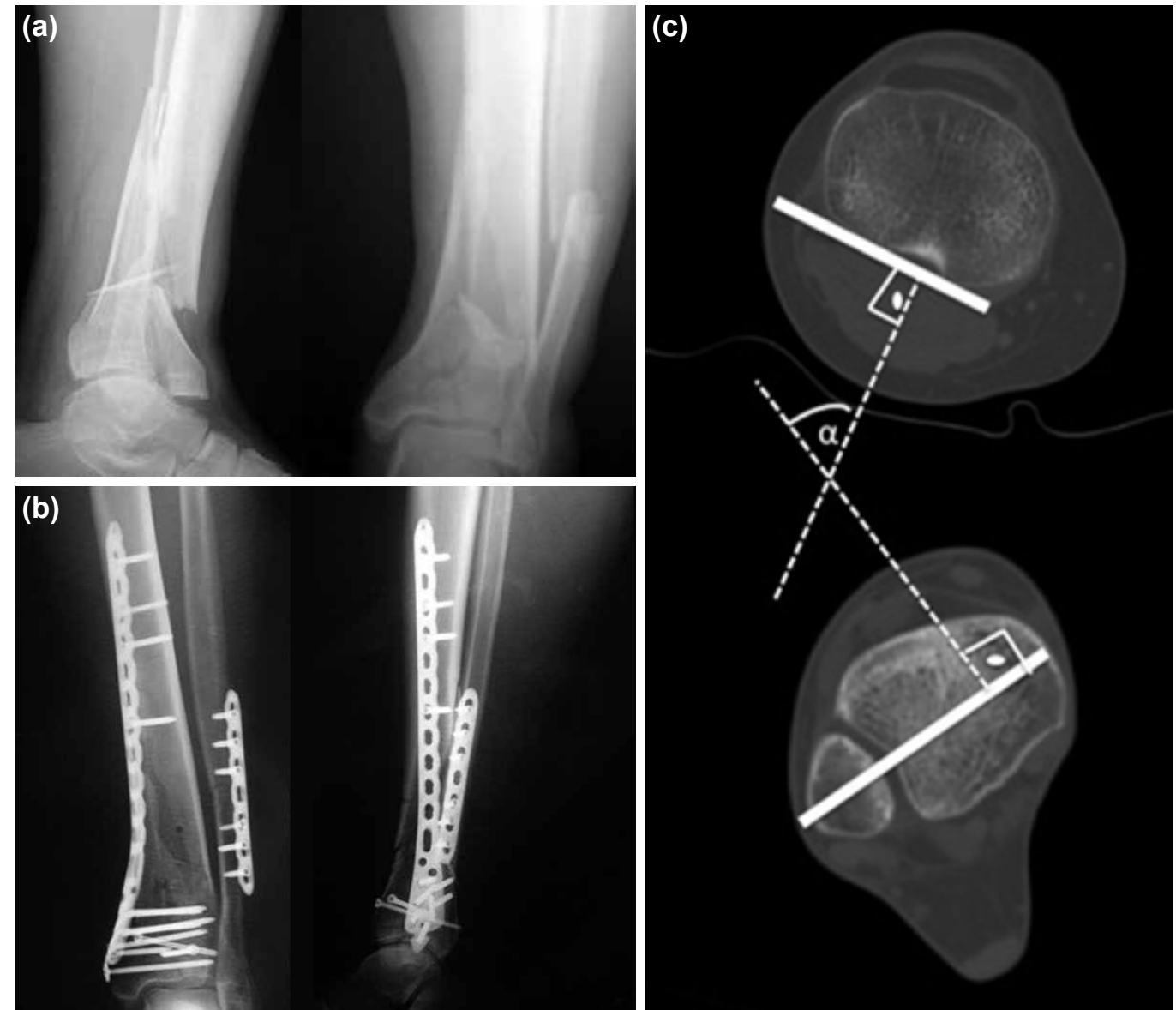

Figure 1. (a) Preoperative radiographs of a 41-year-old patient with distal tibial fracture accompanied by fibular fracture. Tibial fracture extends to the ankle joint. (b) Early postoperative radiographs of the same patient. Intraarticular fragments were fixed with minimal soft tissue dissection. (c) Measurement of tibial torsion.

(4.2\%), 42B Iin 3 (I $2.5 \%), 42 \mathrm{~B} 2$ in 2 (8.3\%), $42 \mathrm{~B} 3$ in $6(25 \%)$, $42 \mathrm{Cl}$ in 2 (8.3\%), 42C2 in I (4.2\%), 43A I in I (4.2\%), $43 \mathrm{~A} 3$ in $4(16.7 \%)$ and $43 C 2$ in $I(4.2 \%)$.

Tibial rotation angle was determined as mean $31.54 \pm 6.00^{\circ}$ (range: $18-45^{\circ}$ ) on healthy side and mean $32.00 \pm 6.24^{\circ}$ (range: $10-43^{\circ}$ ) on operated side.
No statistically significant difference was found between healthy side and operated side with respect to rotation angle ( $p>0.05$ ) (Table 2). No statistically significant relationship was determined between VAS and AOFAS scores and difference between operated side rotation angle and healthy side rotation angle $(p>0.05)$ (Table 3$)$. In I patient, implants were removed due to soft tissue irritation I year after surgery.

Table I. Distribution of descriptive characteristics

\begin{tabular}{|c|c|c|c|c|}
\hline & $\mathbf{n}$ & $\%$ & Minimum-Maximum & Mean $\pm S D$ \\
\hline \multicolumn{5}{|l|}{ Gender } \\
\hline Male & II & 45.8 & & \\
\hline Female & 13 & 54.2 & & \\
\hline Age (years) & & & $19-55$ & $33.67 \pm 10.72$ \\
\hline Body mass index $\left(\mathrm{kg} / \mathrm{m}^{2}\right)$ & & & $20-25$ & $22.04 \pm 1.55$ \\
\hline Follow-up period (months) & & & $|8-5|$ & $20.00 \pm 9.46$ \\
\hline Time to union (weeks) & & & $13-19$ & $15.42 \pm 1.67$ \\
\hline Visual analogue scale score & & & $1-4$ & $2.58 \pm 0.83$ \\
\hline American Orthopaedic Foot and Ankle Society & & & 78-93 & $87.50 \pm 4.05$ \\
\hline
\end{tabular}

SD: Standard deviation. 
Table 2. Tibial rotation angle

\begin{tabular}{lcr}
\hline & \multicolumn{2}{c}{ Tibia rotation angle (degrees) } \\
\cline { 2 - 3 } & Minimum-Maximum & Mean \pm SD \\
\hline Healthy side & $18-45$ & $31.54 \pm 6.00$ \\
Operated side & $10-43$ & $32.00 \pm 6.24$ \\
Difference (Operated-Healthy) & $-12-18$ & $0.46 \pm 7.44$ \\
"P & & 0.766 \\
\hline
\end{tabular}

SD: Standard deviation. "Paired samples t-test.

Table 3. Relationship between TRA and VAS and AOFAS scores

\begin{tabular}{lcc}
\hline & \multicolumn{2}{c}{ TRA difference (operated-healthy) } \\
\cline { 2 - 3 } & \multicolumn{1}{c}{$\mathbf{p}$} & $\mathbf{p}$ \\
\hline VAS & $\mathrm{b}_{-}-0.199$ & 0.350 \\
AOFAS & $\mathrm{c}-0.138$ & 0.521 \\
\hline
\end{tabular}

'Spearman correlation coefficient. 'Pearson correlation coefficient. TRA: Tibia rotation angles; VAS: Visual analogue scale; AOFAS: American Orthopaedic Foot and Ankle Society.

\section{DISCUSSION}

This study has demonstrated that rotational profile of the distal tibia can be observed accurately with standard postoperative CT scans, even when standard intraoperative fluoroscopy was used to reduce malrotation of distal tibial fractures treated with MIPO technique. CT scanning has become the gold standard for assessment of limb rotational alignment. [8-1I] Test is accurate and has good inter- and intra-observer reliability and repeatability. ${ }^{[2]}$ The present study had good intraobserver reliability, as recommended in the literature. The results of this study confirmed that using intraoperative fluoroscopy, cable technique, and uninjured extremity as a reference can decrease incidence of rotational malalignment of distal tibial fractures treated with MIPO.

With the popularity of biological fixation, MIPO is now being used more frequently at trauma centers. MIPO with indirect fracture reduction can lead to higher rates of limb malalignment. ${ }^{\left[{ }^{13-15]}\right.}$ Rotational deformity in the lower extremity has been shown to influence articular cartilage shearing and development of joint arthrosis, leading to clinically relevant degenerative changes. ${ }^{[3,4,16,17]}$ Quality of reduction and limb alignment with use of MIPO technique has not been well documented. The few studies that have documented post-reduction limb rotation following MIPO cite incidence of malrotation $>10^{\circ}$ in $0 \%$ to $9 \%$ of limbs based on clinical examination and side-to-side comparison with the uninjured extremity. ${ }^{[18-22]}$ In the present study, there were no cases with tibial malrotation compared with uninjured side. This was considered to be related to accurate use of intraoperative fluoroscopy and the experience of the surgical team, who were certified in trauma.

In the present study, the uninjured limb was prepared to assess rotation profile of the extremity. Inclusion of the uninjured limb in surgical preparation has been recommended to benefit reduction assessment, and previous studies that have used CT scans to examine uninjured lower limbs for rotation have reported average side-to-side difference in rotation of only $3^{\circ}$ to $4^{\circ} .^{[1]}$ Tornetta has described technique of using distal femoral traction pin and fluoroscopy of both normal and injured extremities to better judge rotation for femoral shaft fractures. ${ }^{[23]}$ In the current study, there was no statistically significant difference between injured and uninjured extremities with respect to rotational alignment $(p=0.766)$. Preparing the uninjured limb as reference for normal rotation and intraoperative cable technique with guidance of fluoroscopy were considered to be beneficial in judging rotation of the injured extremity. However, no convenient and reliable method of assessing intraoperative lower limb rotation has been developed and used consistently. This is an area for further research.

One study concluded that fibular plate fixation increased initial rotational stability of distal third tibia and fibula shaft fractures compared with intramedullary nailing of the tibia alone. ${ }^{[2]}$ Prasad et al. stated that average rotation at the ankle was less, with $7.67^{\circ}$ of external rotation in group with fibula fixed, compared with $10.68^{\circ}$ of external rotation in group with non-fixed fibula $(p=0.01) .{ }^{[25]}$ In the current study, only 3 fibulae were stabilized with open reduction internal fixation technique. There was no statistically significant difference between these 3 cases and non-fixed fibula fractures $(p>0.05)$. However, strength of recommendation is low due to small sample size in each group. Prospective randomized studies could be designed to evaluate difference in rotational malalignment of both groups (fixed and non-fixed fibula).

Soft tissue coverage is weak in the distal tibia metaphyseal region and in the distal diaphysis. Various studies have reported on postoperative wound healing and infection risk in this area. Guo et al. reported wound problems at rate of 
$14.6 \%{ }^{[26]}$ and Lau et al. reported late stage infection following MIPO at $15 \% .{ }^{[27]}$ In the current study, implant was removed in I patient (3.3\%) due to implant irritation.

\section{Limitations of the Study}

Primary limitations of this study were small number of cases and short duration of follow-up. Studies with larger patient population may demonstrate real extent of malalignment after such surgery. In addition, long-term follow-up results may reveal useful results regarding such deformities.

In conclusion, the best method to avoid malrotation during MIPO technique is comparison with the opposite leg and use of intraoperative fluoroscopy and cable technique. It may be appropriate to prepare the normal leg for comparison. Malrotation is best identified by clinical inspection and best quantified by limited CT scan.

\section{Conflict of interest: None declared.}

\section{REFERENCES}

1. Hazarika S, Chakravarthy J, Cooper J. Minimally invasive locking plate osteosynthesis for fractures of the distal tibia--results in 20 patients. Injury 2006;37:877-87. Crossret

2. Ronga M, Longo UG, Maffulli N. Minimally invasive locked plating of distal tibia fractures is safe and effective. Clin Orthop Relat Res 2010;468:975-82. Crossre]

3. Gugenheim JJ, Probe RA, Brinker MR. The effects of femoral shaft malrotation on lower extremity anatomy. Orthop Trauma 2004;18:658-64.

4. Netz P, Olsson E, Ringertz H, Stark A. Functional restitution after lower leg fractures. A long-term follow-up. Arch Orthop Trauma Surg 1991;110:238-41. Crossret

5. Suero EM, Hawi N, Westphal R, Sabbagh Y, Citak M, Wahl FM, et al. The effect of distal tibial rotation during high tibial osteotomy on the contact pressures in the knee and ankle joints. Knee Surg Sports Traumatol Arthrosc 2015 Mar 6.

6. Richmond J, Colleran K, Borens O, Kloen P, Helfet DL. Nonunions of the distal tibia treated by reamed intramedullary nailing. J Orthop Trauma 2004;18:603-10. Crossret

7. van der Schoot DK, Den Outer AJ, Bode PJ, Obermann WR, van Vugt $\mathrm{AB}$. Degenerative changes at the knee and ankle related to malunion of tibial fractures. 15-year follow-up of 88 patients. J Bone Joint Surg Br 1996;78:722-5.

8. Jakob RP, Haertel M, Stüssi E. Tibial torsion calculated by computerised tomography and compared to other methods of measurement. J Bone Joint Surg Br 1980;62:238-42.

9. Jend H, Heller M, Dallek M, Schoettle H. Measurement of tibial torsion by computer tomography. Acta Radiol 1981;22:271-5. Crossre.

10. Murphy SB, Simon SR, Kijewski PK, Wilkinson RH, Griscom NT. Femoral anteversion. J Bone Joint Surg Am 1987;69:1169-76. Crossree
11. Strecker W, Keppler P, Gebhard F, Kinzl L. Length and torsion of the lower limb. J Bone Joint Surg Br 1997;79:1019-23. Crossre

12. Puloski S, Romano C, Buckley R, Powell J. Rotational malalignment of the tibia following reamed intramedullary nail fixation.J Orthop Trauma 2004;18:397-402. Crossre

13. Neer CS, Grantham SA, Shelton ML. Supracondylar fracture of the adult femur. A study of one hundred and ten cases. J Bone Joint Surg Am 1967;49:591-613. Crossre

14. Schatzker J, Home G, Waddell J. The Toronto experience with the supracondylar fracture of the femur, 1966-72. Injury 1974;6:113-28. Crossre.

15. Williams J, Gibbons M, Trundle H, Murray D, Worlock P. Complications of nailing in closed tibial fractures. J Orthop Trauma 1995;9:47681. Crossre

16. Kettelkamp DB, Hillberry BM, Murrish DE, Heck DA. Degenerative arthritis of the knee secondary to fracture malunion. Clin Orthop Relat Res 1988;234:159-69. Crossre

17. van der Schoot DK, Den Outer AJ, Bode PJ, Obermann WR, van Vugt $\mathrm{AB}$. Degenerative changes at the knee and ankle related to malunion of tibial fractures. 15-year follow-up of 88 patients. J Bone Joint Surg Br 1996;78:722-5.

18. Cole PA, Zlowodzki M, Kregor PJ. Treatment of proximal tibia fractures using the less invasive stabilization system: surgical experience and early clinical results in 77 fractures. J Orthop Trauma 2004;18:528-35. Crossre.

19. Kregor PJ, Stannard JA, Zlowodzki M, Cole PA. Treatment of distal femur fractures using the less invasive stabilization system: surgical experience and early clinical results in 103 fractures. J Orthop Trauma 2004;18:509-20. Crossre

20. Ricci WM, Rudzki JR, Borrelli J Jr. Treatment of complex proximal tibia fractures with the less invasive skeletal stabilization system. J Orthop Trauma 2004;18:521-7. Crossret

21. Stannard JP, Wilson TC, Volgas DA, Alonso JE. The less invasive stabilization system in the treatment of complex fractures of the tibial plateau: short-term results. J Orthop Trauma 2004;18:552-8. Crossref

22. Weight $M$, Collinge C. Early results of the less invasive stabilization system for mechanically unstable fractures of the distal femur (AO/OTA types A2, A3, C2, and C3).J Orthop Trauma 2004;18:503-8. Crossre.

23. Tornetta P, Ritz G, Kantor A. Femoral torsion after interlocked nailing of unstable femoral fractures. J Trauma 1995;38:213-9. Crossre.

24. Morrison KM, Ebraheim NA, Southworth SR, Sabin JJ, Jackson WT. Plating of the fibula. Its potential value as an adjunct to external fixation of the tibia. Clin Orthop Relat Res 1991;266:209-13.

25. Prasad M, Yadav S, Sud A, Arora NC, Kumar N, Singh S. Assessment of the role of fibular fixation in distal-third tibia-fibula fractures and its significance in decreasing malrotation and malalignment. Injury 2013;44:1885-91. Crossre.

26. Guo JJ, Tang N, Yang HL, Tang TS. A prospective, randomised trial comparing closed intramedullary nailing with percutaneous plating in the treatment of distal metaphyseal fractures of the tibia.J Bone Joint Surg Br 2010;92:984-8. Crossre

27. Lau TW, Leung F, Chan CF, Chow SP. Wound complication of minimally invasive plate osteosynthesis in distal tibia fractures. Int Orthop 2008;32:697-703. Crossre 


\title{
ORİIINAL ÇALIŞMA - ÖZET
}

\section{Distal tibia kırıklarının minimal invaziv tespiti rotasyonel deformiteye neden olmaz: Yirmi dört hastanın bilgisayarlı tomografi incelemesi \\ Dr. Mehmet Mesut Sönmez, ${ }^{1}$ Dr. Deniz Gülabi, ${ }^{2}$ Dr. Meriç Uğurlar, ${ }^{1}$ Dr. Metin Uzun, ${ }^{4}$ Dr. Sezgin Sarban, ${ }^{5}$ Dr. Ali Şeker ${ }^{3}$}

\author{
${ }^{1}$ Şişli Etfal Eğitim ve Araştırma Hastanesi, Ortopedi ve Travmatoloji Kliniği, İstanbu \\ ${ }^{2}$ Kartal Dr. Lütfi Kırdar Eğitim ve Araştırma Hastanesi, Ortopedi ve Travmatoloji Kliniği, İstanbul \\ ${ }^{3}$ Medipol Üniversitesi Tıp Fakültesi, Ortopedi ve Travmatoloji Anabilim Dalı, İstanbul \\ ${ }^{4}$ Acıbadem Üniversitesi Tıp Fakültesi, Ortopedi ve Travmatoloji Anabilim Dalı, İstanbu \\ ${ }^{5}$ International Hospital, Ortopedi ve Travmatoloji Kliniği, İstanbul
}

AMAÇ: Tibial rotasyon prosimal eklemin transvers planda distal ekleme göre rotasyonda olmasıdır. Bu çalışmanın amacı minimal invaziv plaklama yöntemi (MiPO) ile tedavi edilen distal tibia kırıklarında, malrotasyonun bilgisayarlı tomografi (BT) ile tespit edilimesi, rotasyonel farkın klinik sonuçlar ve Vizüel Analog Skala (VAS) skoru üzerine etkisini araştırmaktı.

GEREÇ VE YÖNTEM: 20I0-20I 2 yılları arasında kapalı distal tibia kırığı nedeniyle MiPO yöntemiyle ameliyat edilen 24 hasta çalışmaya dahil edildi. On dereceden fazla rotasyon farkı malrotasyon olarak kabul edildi. Ameliyat edilen bacak $0.5 \mathrm{~mm}$ aralıklarla alınan üç boyutlu BT kesitleriyle radyoloji bölümü tarafından değerlendirildi. İki alt ekstremite arasındaki 10 dereceden fazla fark malrotasyon olarak kabul edildi. Tüm hastalar son takiplerinde klinik (VAS ve Amerikan Ortopedi Ayak ve Ayak Bileği Topluluğu [AOFAS]) ve radyolojik olarak değerlendirildi.

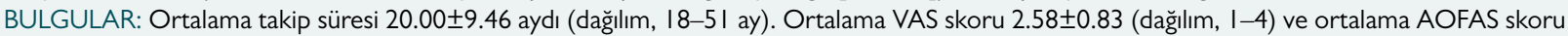
$87.50 \pm 4.05$ (dağılım, 78-93) idi. Ortalama tibia rotasyon açısı sağlam tarafta $31.54^{\circ} \pm 6.00^{\circ}$ (dağılım, $18^{\circ}-45^{\circ}$ ) ve ameliyatlı tarafta ise $32.00^{\circ} \pm 6.24^{\circ}$ (dağılım, $\left.10^{\circ}-43^{\circ}\right)$ idi. İstatiksel olarak anlamlı fark saptanmadı $(p>0.05)$.

TARTIŞMA: Minimal invaziv plaklama yöntemiyle distal tibia kırıklarının tedavi edilmesinde ameliyat sırasında skopi kullanılması, kablo tekniğinin ve sağlam tarafın referans olarak kullanılma yöntemi rotasyonel dizilim sorununu azaltacağı kanaatindeyiz.

Anahtar sözcükler: BT; distal tibia kırı̆ı; malrotasyon; MiPO.

Ulus Travma Acil Cerrahi Derg 2017;23(2):|44-149 doi: 10.5505/tjtes.2016.59I53 